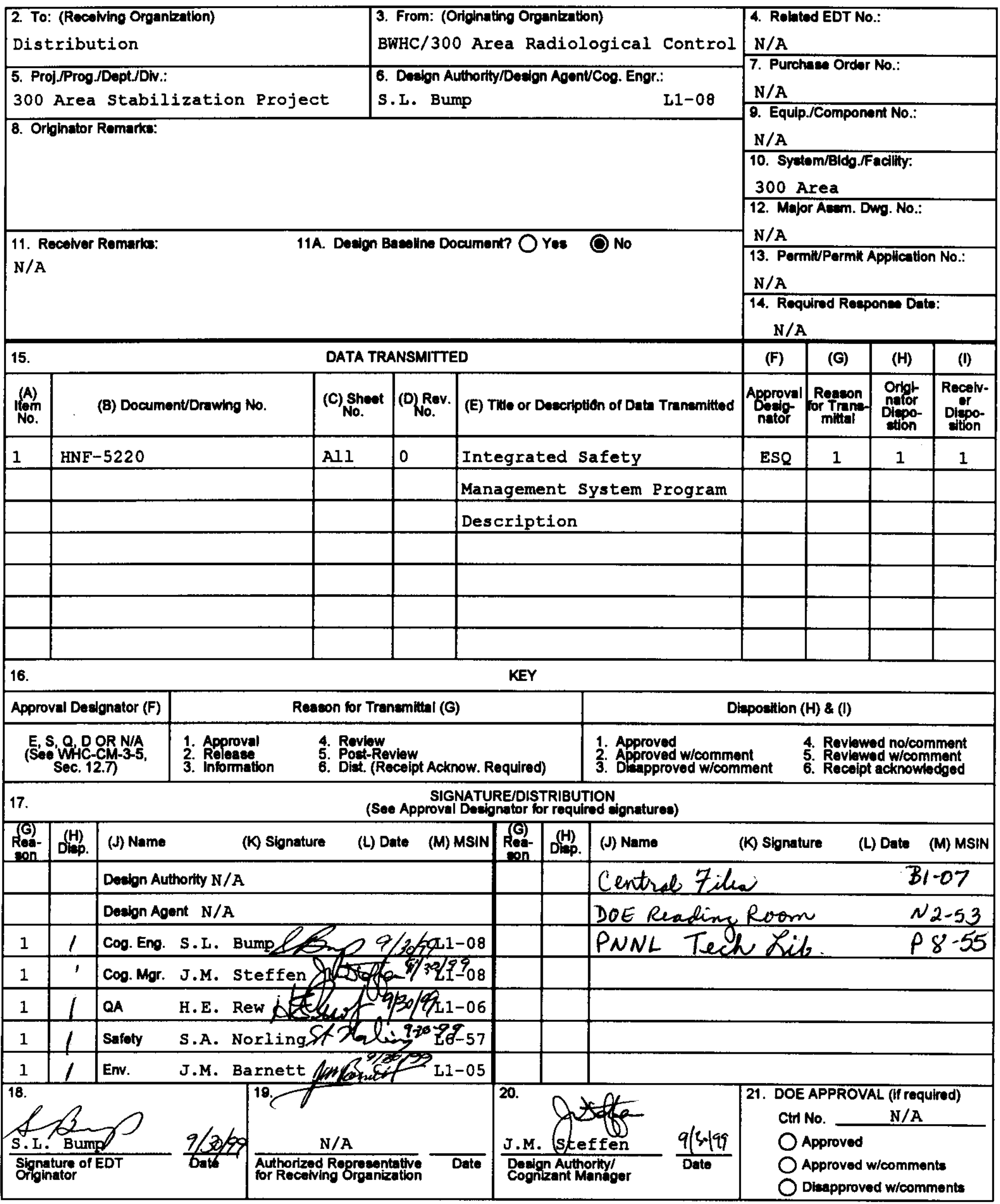


HNF-5220, Rev. 0

September 1999

\title{
INTEGRATED SAFETY MANAGEMENT SYSTEM (ISMS) PROGRAM DESCRIPTION
}

\author{
SL Bump \\ B\&W Hanford Company, Richland, WA 99352 \\ U.S. Department of Energy Contract DE-AC06-96RL13200

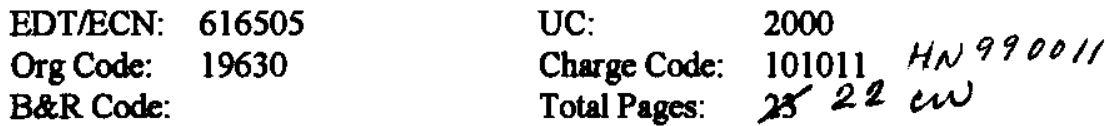

Key Words: Integrated Safety Management System (ISMS)

Abstract: This document describes the ISMS Program for the 300 Area and lists the procedures necessary to implement the program.

TRADEMARK DISCLAIMER. Reference herein to any specific commercial product, process, or service by trade name. trademark, manufacturer, or otherwise, does not necessarily constitute or fmply its endorsement, recommendation, or favoring by the United States Government or any agency thereof or its contractors or subcontractors.

Printed in the United States of America. To obtain copies of this document, contact: Document Control Services. P.0. Box 950, Mallstop H6-08, Richland WA 99352, Phone (509) 372-2420; Fax (509) 376-4989.
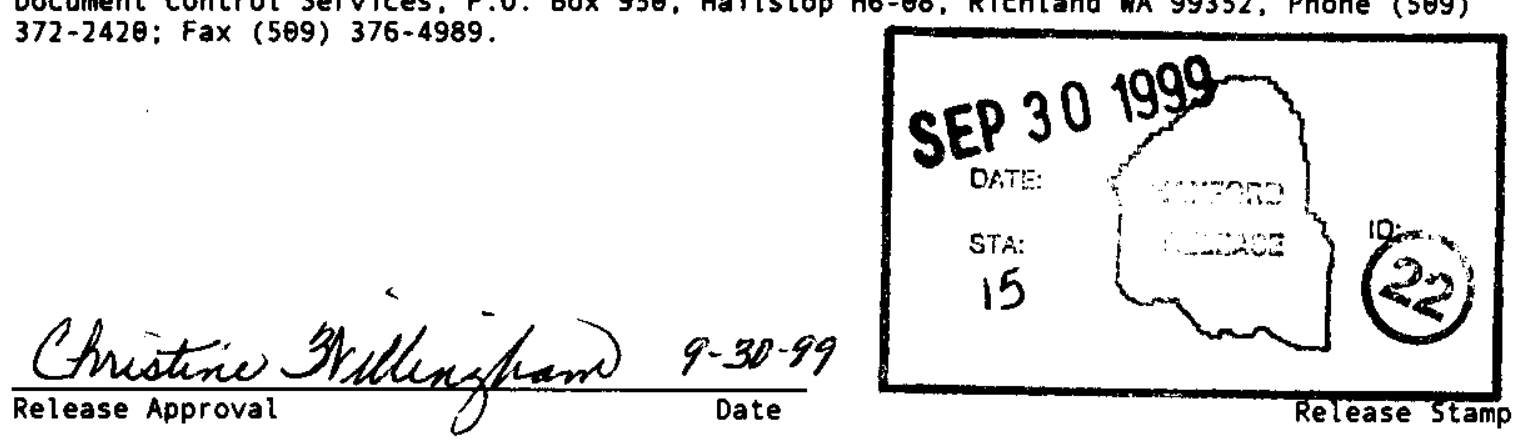


\section{ISMS PROGRAM DESCRIPTION}

\section{INTRODUCTION}

The Department of Energy (DOE), in response to Defense Nuclear Facilities Safety Board (DNFSB) Recommendation 95-2, has committed to implementing a plan that will institutionalize an Integrated Safety Management System (ISMS) across all DOE facilities. The DOE ISMS policy is provided in DOE Policy P450.4 Safety Management System Policy which requires DOE and its contractors to "systematically integrate safety into management and work practices at all levels so that missions are accomplished while protecting the public, the worker, and the environment." ISMS is also the integrating management system for all existing safety and quality programs, including initiatives such as Automated Job Hazards Analysis (AJHA), Enhanced Work Planning (EWP), Voluntary Protection Program (VPP), and Conduct of Operations.

The Project Hanford Management Contract (PHMC) Integrated Environment, Safety and Health Management System (ISMS) Plan, HNF-MP-003, documents the approach to implementing ISMS for the PHMC. The 300 Area Facility Stabilization Project (FSP) has prepared this document to describe its ISMS program, consistent with the expectations of the PHMC ISMS Plan, the DOE Policy P450.4, DOE Policy P450.6 Secretarial Policy Statement - Environment, Safety and Health oversight, DOE Policy P450.5 Line Environment, Safety and Health Oversight, and the Department of Energy Acquisition Regulation (DEAR) clause 970.5204-2, Integration of Environment, Safety and Health into Work Planing and Execution. These policies are addressed specifically in the PHMC ISMS Plan and are implemented by the flowdown of requirements stated in that plan. The 300 Area ISMS program Description provides a description of the facility specific implementation of the PHMC ISMS Plan, HNF-MP-003. Implementation of the facility specific ISMS program description serves as the basis for addressing the DOE policy statements and DEAR clause requirements. The 300 Area FSP program description is applicable to all facilities that use the 300 Area FSP work control process.

As stated in the DOE Safety Management System Policy, DOE P 450.4, the ISMS Guiding Principles are the fundamental policies which guide actions, from development of safety directives to performance of work. The safety management Core Functions provide the necessary structure for any work activity that could potentially affect the public, the workers, and the environment. The Core Functions are applied as a continuous cycle with the degree of rigor appropriate to address the type of work activity and the hazards involved.

The PHMC ISMS consists of eleven Guiding Principles and seven Core Functions as identified below:

Guiding Principles:

1. Line Management for Safety and Environmental Performance Defined. Line management is directly responsible for protecting the workers, the public and the environment.

2. Clear Roles and Responsibilities Defined. Clear and unambiguous lines of authority and responsibility for ensuring ES\&H performance are established, documented, and communicated at all organizational and subcontractor levels to achieve effective safety and environmental management.

3. Competence Commensurate with Responsibility. Personnel possess the experience, knowledge, skills and abilities that are necessary to discharge their responsibilities safely. 


\section{ISMS PROGRAM DESCRIPTION}

4. Balanced Priorities. Protecting the workers, the public and the environment is a priority whenever work activities are planned and performed. Therefore, resources are effectively allocated with balanced priorities to address safety, programmatic and operational considerations.

5. Safety and Environmental Standards and Requirements Defined. Before work is performed, the hazards and environmental impacts are identified, and ES\&H standards and requirements are established.

6. Hazard Controls Tailored to Work Performed. Engineering and administrative controls to prevent and mitigate hazards are tailored to the work activity being performed and the associated hazards.

7. Operations Authorization. The conditions and requirements for the safe and environmentally protective execution of work are established and clearly communicated.

8. Worker Involvement. Workers are actively involved in preparing for work, including planning, hazard and environmental impact identification and analysis, implementation of controls, and readiness review.

9. Communication and Stakeholder Involvement. Open and effective internal and external communication supports management of ES\&H issues and initiatives.

10. Continuous Improvement. Workers, supervisors, and management continually check the adequacy of work processes, procedures, and equipment, and correct deficiencies when identified.

11. Senior Management Involvement. Senior management is actively engaged in the implementation and improvement of the ISMS.

\section{Core Functions:}

1. Establish ES\&H Policy. ES\&H policy is clearly documented and communicated to all employees.

2. Define the Scope of Work. Missions are translated into work by setting expectations, allocating resources, and prioritizing tasks.

3. Identify Hazards and Requirements. Hazards, environmental impacts and ES\&H requirements associated with the work are identified and categorized.

4. Analyze Hazards and Implement Controls. Job hazard analysis and work planning are performed, and proper preventive and mitigative safety controls are in place, in accordance with standards and requirements, to assure protection of the public, workers and the environment.

5. Perform Work Within Controls. Performing work includes preparing for the work, confirming readiness to perform the work, and performing the work in a safe, environmentally protective and efficient manner.

6. Provide Feedback and Continuous Improvement. Readiness is confirmed before work begins, and performance is monitored throughout the work activity. Post-jobs, management assessments, and independent assessments are mechanisms used to obtain data for analysis and feedback, to measure performance against expectations, and identify lessons learned and improvement opportunities.

7. Management Review. Senior management will review ISMS to ensure that it continues to be effective. 


\section{ISMS PROGRAM DESCRIPTION}

\section{$1.1 \quad$ ISMS SYSTEM DIAGRAM}

A diagram of the 300 Area Facility Stabilization Project (FSP) ISMS Program Description is provided in Figure 1. This diagram illustrates the relationship of the guiding principles, core functions and implementing documents as described in this ISMS Description. For example, Core Function 2, "Define Scope of Work," and Guiding Principle 4, "Balanced Priorities," are related. The guiding principles presented across the top of the diagram support the core functions aligned just below them.

The 300 Area FSP and Project Hanford Management System (PHMS) policies, plans, and procedures used to implement the Guiding Principles and Core Functions are also identified in Figure 1.

\subsection{ISMS GUIDING PRINCIPLES AND CORE FUNCTIONS}

This section describes the guiding principles and core functions set forth in the PHMC ISMS Plan, and discusses how they are applied at the 300 Area FSP.

\subsection{GUIDING PRINCIPLES}

The ISMS Guiding Principles are the fundamental policies which guide activities from the development of safety directives to the performance of work. This section describes how each of the Guiding Principles is implemented at the 300 Area FSP.

\subsubsection{Line Management Responsibility for Safety and Environmental Performance Defined}

This guiding principle is an intrinsic part of all seven Core Functions. Line management responsibility must be defined for all aspects of the work process.

As defined in the 300 Area FSP Administrative Manuals, HNF-IP-1264 and FSP-FSS-5-35, line management is responsible for ensuring work is planned and executed in a safe manner and in accordance with applicable requirements. Line management is personally responsible for the safety of personnel and property within their respective areas of operation. At all times, line management requires work be done in accordance with approved work documents and procedures.

Line management is responsible for ensuring personnel are properly trained and qualified to perform assigned tasks in a manner that minimizes risk to themselves, co-workers, the public, the environment, and plant equipment. Line Management ensures both facility and subcontractor personnel are qualified using the Training Matrix System which defines the training qualifications of each individual worker.

\subsubsection{Clear Roles and Responsibilities Defined}

This guiding principle is an intrinsic part of all seven Core Functions. Clear roles and responsibilities must be defined for all aspects of the work process. 


\section{ISMS PROGRAM DESCRIPTION}

Clear and unambiguous lines of authority and responsibility for ensuring ES\&H performance are established, documented, and communicated at all organizational and subcontractor levels to achieve effective safety and environmental management. The 300 Area Stabilization Project Standing Instruction, SI-300 Area-014, outlines the organizational structure including roles and responsibilities. Additional task-specific responsibilities are defined in the individual administrative procedures contained in HNF-IP-1264 and FSP-FSS-5-35. In addition, individual job descriptions for each employee contain job specific responsibilities and ES\&H performance expectations.

\subsubsection{Competence Commensurate with Responsibilities}

This guiding principle is an intrinsic part of all seven Core Functions. Personnel involved with all aspects of the work process must understand their responsibilities and be qualified to perform work according to applicable procedures.

It is necessary that personnel possess the experience, knowledge, skills and abilities that are necessary to perform their responsibilities safely. 300 Area FSP personnel are trained and qualified to perform the work to which they are assigned. Minimum requirements are defined in individual position descriptions, which are maintained in the individuals training file. HNF-IP1264 , Sections 2.15 and 2.16 , specifies the training responsibilities within the operating organization, and requirements for new and continuing employees to ensure they are qualified to perform their job assignments. HNF-IP-1281 assigns the Project Managers the responsibility for ensuring that all personnel performing work at the facility are qualified for their assigned tasks. Line managers are responsible for verifying qualification of personnel before assigning them to perform work.

The Training Implementation Matrix, HNF-IP-1264, and FSP-FSS-05-35 specify qualifications for managers, engineers, Configuration Control Authority (CCA) and On-Call Building Emergency Director (OBED), Person In Charge (PIC), radiological control personnel, operators, and maintenance personnel.

\subsubsection{Balanced Priorities}

This guiding principle is related to CF-2 Define Scope of Work. Balanced priorities, based on safety and programmatic drivers, are an inherent part of defining the appropriate work scope for the facility.

Protecting the workers, the public and the environment is a priority whenever work activities are planned and performed. Therefore, resources are effectively allocated with balanced priorities to address safety, programmatic and operational considerations. This is performed at all levels of schedule development including MYWP, plan of the week, and plan of the day. The 300 Area FSP Director leads the annual effort to define and prioritize the work scope for operations and maintenance, with input from the other managers. The Director continues to define and reprioritize work identified as a result of extended Facility Evaluation Board reviews, EH-10 initiatives, etc. throughout the fiscal year. Roles and responsibilities of the management team are defined in SI-300 Area-014 300 Area Stabilization Project Organizational Structure. 


\section{ISMS PROGRAM DESCRIPTION}

\subsubsection{Safety and Environmental Standards and Requirements Identified}

This guiding principle is related to CF-3 Identify Hazards and Requirements. Identifying potential hazards and environmental impacts, and defining applicable ES\&H requirements is important to ensure hazards are adequately controlled and requirements are met.

The Automated Job Hazard Analysis (AJHA) process is the principle method used at the 300 Area FSP to ensure hazards, environmental impacts, and ES\&H standards and requirements are identified and implemented. The AJHA is a computer-based process that systematically reviews the proposed work scope and involves workers and subject matter experts in identifying hazards and requirements.

ES\&H requirements are conveyed to subcontractors through contracts and task order agreements. This is defined in FSP-004 Facility Stabilization Projects Subcontractor Safety and Health Oversight.

\subsubsection{Hazard Controls Tailored to Work Being Performed}

This guiding principle is related to CF-4 Analyze Hazards and Environmental Impacts. Engineering and administrative controls identified to prevent and mitigate analyzed hazards are tailored to the work activity being performed and the associated risk.

A graded approach to individual work activities based on risk and complexity is necessary to effectively implement safe, environmentally protective and cost-effective controls. The work planning process considers routine versus non-routine tasks when determining the proper balance of work instructions, worker supervision, authorization requirements, and craft skills.

Facility controls, including engineered, administrative, and personal protective equipment, ensure ES\&H requirements are met and hazards and environmental impacts are prevented or mitigated. The controls and requirements for performance of work at 300 Area FSP are established in the Authorization Envelope, facility procedures, and work control documents. Facility activities are maintained within the established Authorization Envelope and procedural requirements by performing AJHAs in accordance with SI-300 Area -025 and Unreviewed Safety Question screenings in accordance with HNF-IP-1264, Section 2.7 and FSP-FSS-05-35, Section 01-11 as necessary. Pre-job briefings are used when appropriate to communicate identified hazards and environmental impacts to the worker.

\subsubsection{Operations Authorization}

This guiding principle is related to CF-5 Perform Work within Controls. Authorization prior to proceeding with work ensures the facility and the worker are adequately prepared and the appropriate controls have been identified.

The formality and rigor of ensuring readiness and the level of operations authorization is based on the hazard and complexity of the work being performed and is defined in the 300 Area FSP work management process. The pre-job briefing is the last confirmation of readiness before performing individual work activities and provides the work team with a collective understanding of the task to be completed, requirements for performing the task, identified hazards and environmental 


\section{ISMS PROGRAM DESCRIPTION}

impacts, and necessary controls. Release of work is done in accordance with HNF-IP-1264, Section 4.1 and FSP-FSS-05-35, Section 02-01.

\subsubsection{Worker Involvement}

This guiding principle is related to CF-1 Establish ES\&H Policy, CF-2 Define Scope of Work, CF-3 Identify Hazards and Requirements, CF-4 Analyze Hazards and Environmental Impacts, CF-5 Perform Work within Controls, and CF-6 Feedback and Continuous Improvement. Worker involvement is necessary during all aspects of the work process, excluding management review, to allow workers to share their knowledge and experience, improve work efficiency, and ensure safe work performance.

300 Area FSP personnel are actively involved in preparing for work including planning, hazard and environmental impact identification, implementation of controls, and readiness to perform work. Worker involvement is primarily ensured by implementation of the AJHA process in accordance with SI-300 Area -025. AJHAs are completed with the involvement of workers, subject matter experts, and oversight organizations. The AJHA process is implemented early in the work task development process to ensure that early worker involvement is obtained. As described in the facility procedures, each worker has the right, responsibility, and authority to report unsafe or environmentally unsound conditions or practices and stop work without fear of reprisal.

\subsubsection{Communications and Stakeholder Involvement}

This guiding principle is related to CF-1 Establish ES\&H Policy, CF-2 Define Scope of Work, CF-3 Identify Hazards and Requirements, CF-4 Analyze Hazards and Environmental Impacts, CF-5 Perform Work within Controls, and CF-6 Feedback and Continuous Improvement. Open and effective internal and external communication supports the effective management of ES\&H issues and initiatives during all aspects of the work process.

BWHC/300 Area FSP operations are developed and executed with the involvement of all interested stakeholders, including federal and state government, the public and private interests. Communications occur on many levels, from media press releases and news reports to individual employee meetings and pre-job briefings. Examples of internal communications include senior staff meetings, employee staff and safety meetings, pre-job briefings, plan of the day and other planning meetings, all-hands meetings and crew briefings. External communications include public meetings, Hanford Advisory Board meetings, and project specific meetings with regulators and DOE personnel.

\subsubsection{Continuous Improvement}

This guiding principle is related to CF-6 Feedback and Continuous Improvement. Feedback information on the adequacy of controls and opportunities for improving the execution and planning of work are identified and implemented to continuously improve work performance.

Workers, supervisors, and management continually check the adequacy of work processes, procedures, and equipment, and correct deficiencies when identified. As defined in the 300 Area FSP work management procedures (HNF-IP-1264, Section 4.1 and FSP-FSS-05-35, Section 0201), personnel participate in critiques, post-job reviews, and post ALARA review meetings to 


\section{ISMS PROGRAM DESCRIPTION}

improve work performance and efficiency. Routine internal and external assessments are also performed are the facility to identify areas for improvements.

\subsubsection{Senior Management Involvement}

This guiding principle is related to CF-7 Management Review. Senior management must be actively engaged in the implementation and improvement of ISMS through establishment of policy, participation in assessments and reviews, and employee interaction.

300 Area FSP management directs the implementation and improvement of ISMS through procedure development, participation in internal assessments and reviews, corrective action management, and interaction with employees. 300 Area FSP management will also participate in the internal readiness review in support of declaration of readiness for Phase I/II verification and direct closure of related corrective actions. Senior Management involvement in the assessment program is described in HNF-IP-1264, Section 2.10, and FSP-FSS-05-35, Section 01-16.

\subsection{CORE FUNCTIONS}

The seven core functions form the foundation for planning and executing work in accordance with the ES\&H policy and the guiding principles as defined above. These core functions are further broken down into facility and activity level expectations. The relationship between the core functions and the expectations is shown in Figure 1. The implementing procedures for each Facility Expectation are detailed in Table 1. The Activity level expectations are given in Table 2 for reference and are performance based. Meeting these expectations ensures that each core function is fully implemented. Implementation of the core functions is the basis for complying with the ES\&H Policy.

\subsubsection{Establish ES\&H Policy}

The PHMC ES\&H policy is described in the PHMC Management and Integration (M\&I) Plan, HNF-MP-001, Attachment 1, Environment, Safety and Health Policy. It is restated in the PHMC ISMS Plan, HNF-MP-003. This policy is consistent with the DOE Policy on ISMS, DOE P 450.4, Safety Management System Policy and the DOE-RL ES\&H Policy, RLPD 450.1, Hanford Environment, Safety and Health Policy. The requirements in the PHMC ISMS Plan are flowed down to the PHMC facilities and reflected in the facility ISMS Program Descriptions.

The 300 Area FSP communicates the facility specific aspects of the ES\&H Policy to personnel and lower tier subcontractors through the use of PHMC and 300 Area FSP policies and implementing procedures. In addition, training programs such as Hanford General Employee Training (HGET) provide an avenue to communicate the ES\&H policy.

\subsubsection{Define Scope of Work}

The Fiscal Year (FY) planning is initiated annually through the direction received by the PHMC from the RL Planning and Integration Division (PID). The guidance from RL to FDH provides Budget Updating Guidance consistent with the Basic Planning and Work Performance of Hanford Site Environmental Management Activities (DOE/RL-97-52) and in accordance with Contract No. DE-AC06-96RL13200. Site-wide guidance and project-specific guidance is provided for updating the Multi-Year Work Plans (MYWP) for each of the PHMC Projects. This guidance is 


\section{ISMS PROGRAM DESCRIPTION}

then conveyed by FDH to the Major Sub-Contractors and hence to the specific projects (e.g., BWHC/300 Area FSP). Ongoing interactions and dialogue among RL, prime contractors, regulators, stakeholders and Tribal Nations counterparts is expected to occur at the project level during updating of the MYWP. The MYWP provides the formal documentation of Hanford Project Baselines. These baselines represent the life cycle of each project area, with detail information for the first three years, and higher level format for the out-years.

Schedules are revised/updated to reflect current planning guidance as received and negotiated. The schedules are then resource loaded with the support of the Project Managers, Functional Managers, Cost Account Managers and topic experts. The work scope definition, the resource requirements and the schedules are compiled in the upcoming FY MYWP which is received by BWHC, FDH, and RL. The MYWP is approved by October 1 and implemented for the current FY.

Facility operations, maintenance, and upgrades are based on the approved budget and schedule and are controlled by the use of a facility level schedule and associated work control system.

\subsubsection{Identify Hazards and Requirements}

The 300 Area FSP Authorization Envelope identifies the facility Safety Authorization Basis documents, Requirements documents, and Environmental documents. The Safety Authorization Basis analyzes current facility activities and hazards and develops the appropriate controls to protect the onsite worker and public. Changes to the facility or new work activities are evaluated using the Unreviewed Safety Question process to ensure all work remains within analyzed conditions.

The 300 Area FSP also uses the site Automated Job Hazards Analysis (AJHA) review process on all work activities and procedures. The AJHA is a computer-based process that systematically reviews the proposed work scope and involves workers and subject matter experts in identifying hazards and requirements.

\subsubsection{Analyze Hazards and Implement Controls}

Controls are developed as necessary to mitigate hazards and accidents analyzed in the 300 Area FSP Safety Authorization Basis. Changes to the facilities or new work activities are evaluated using the Unreviewed Safety Question process to ensure the facilities maintain operations within the approved controls.

For a given work activity, the 300 Area FSP AJHA and work management process are used to identify controls for the associated safety and environmental hazards and requirements. These controls ensure that ES\&H standards and requirements are met and safety and environmental hazards are appropriately addressed. These controls are documented in procedures and work documents.

\subsubsection{Perform Work Within Controls}

Using weekly scheduling meetings, individual work activities are scheduled to be worked in accordance with their priority and impact on facility safety and mission. Adjustments are made on a daily basis utilizing a Plan of the Day (POD). 


\section{ISMS PROGRAM DESCRIPTION}

Staff members conduct the work in accordance with the technical work documents and procedures that have been scheduled and released for work. Compliance with the technical work instructions and procedures is mandatory and is considered a basic Conduct of Operations expectation. Work activities are assigned a person in charge (PIC) that is responsible to work with employees to resolve safety issues and ensure the work can be done safely and in compliance with identified controls. Pre-job briefings are conducted to ensure workers understand the scope of the work and the required controls. When abnormalities occur with the work or documentation questions arise, personnel are expected to stop work and obtain proper resolution before continuing.

\subsubsection{Feedback and Improvement}

As defined in 300 Area FSP work management procedures, personnel participate in post-job and post ALARA review meetings to improve work performance and efficiency. Routine safety, quality, and management assessments are also performed to identify areas for improvements. Financial progress is monitored monthly in internal project review meetings.

Internal self-assessment findings and external review findings are tracked in a corrective management system to ensure proper resolution. In each case the programs are designed to focus on continued improvement.

\subsubsection{Management Review}

300 Area FSP management participates in internal reviews, reviews assessment results, and directs corrective actions and improvements. These reviews include the facility Management Assessment Program, Occurrence Reporting and Processing System, Root Cause, Facility Evaluation Board reviews, Performance Indicators, PODs, etc. 300 Area FSP management will also participate in the ISMS Phase I/II internal assessment and direct closure of related corrective actions. 
Figure 1. 300 Area FSP ISMS Diagram
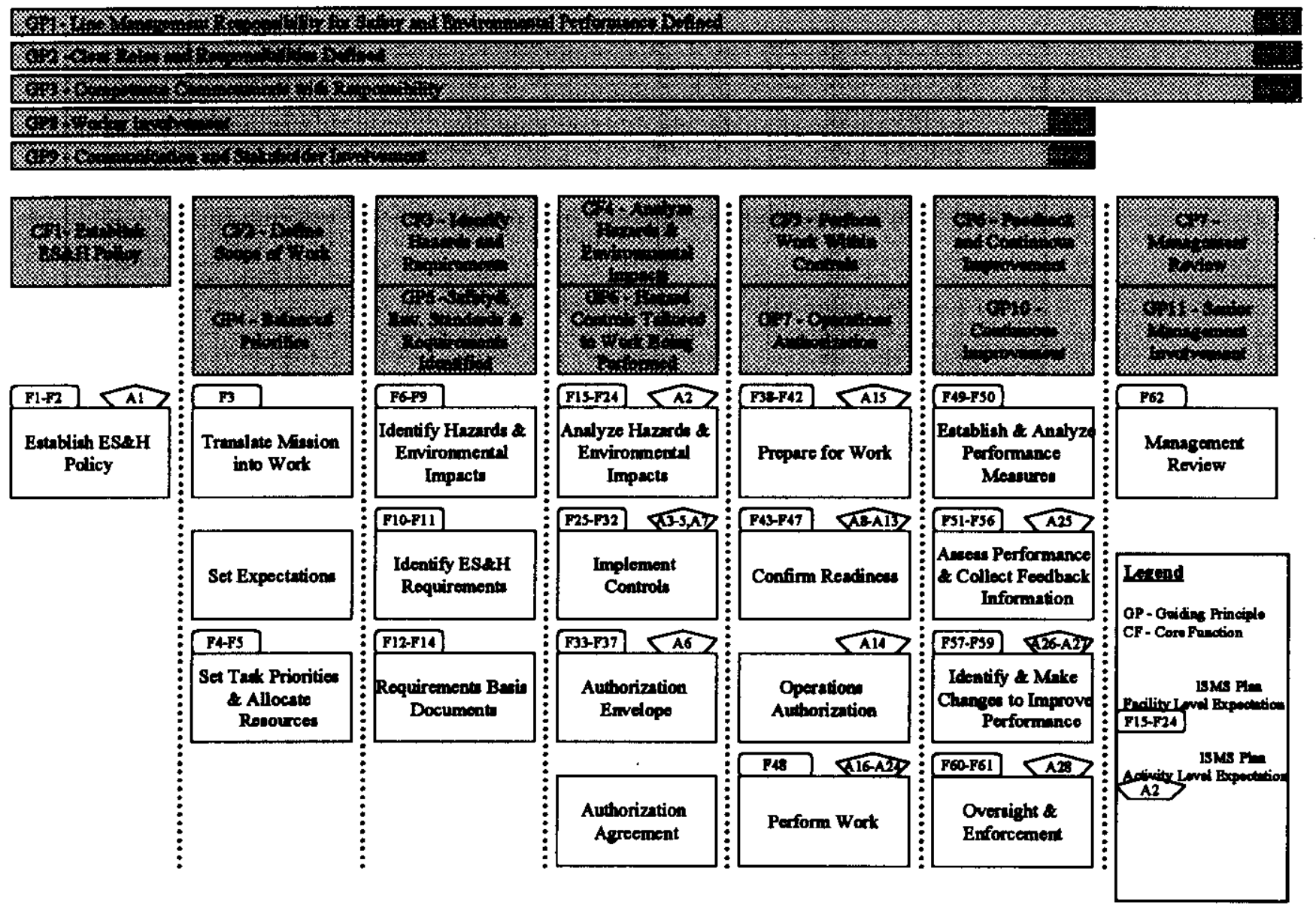


\section{ISMS Program Description}

TABLE 1

\begin{tabular}{|c|c|c|}
\hline NO. & EXPECTATION STATEMENT & IMPLEMENTING DOCUMENTS \\
\hline F01 & $\begin{array}{l}\text { Major Subcontractors communicate the ES\&H } \\
\text { policy to their work force including lower tier } \\
\text { subcontractors. }\end{array}$ & $\begin{array}{l}\text { HNF-MP-001, Management and Integration Plan } \\
\text { HNF-PRO-074, Safety Responsibilities. } \\
\text { HNF-PRO-075, Safety Communications. } \\
\text { HNF-IP-1264, 324/327 Facilities Stabilization Projects Administrative } \\
\text { Manual. }\end{array}$ \\
\hline F02 & $\begin{array}{l}\text { Major Subcontractors adhere to the ES\&H } \\
\text { policy and ensure that activities are carried out } \\
\text { consistent with the policy. }\end{array}$ & $\begin{array}{l}\text { HNF-MP-003, Integrated ES\&H Management System Plan } \\
\text { HNF-5053, ES\&H Policy } \\
\text { HNF-PRO-074, Safety Responsibilities } \\
\text { HNF-IP-1264, 324/327 Facility Stabilization Project Administration Manual } \\
\text { HNF-IP-1289, 324/327 Building Stabilization/Deactivation Project } \\
\text { Management Plan (Section } 9 \text { and 10). }\end{array}$ \\
\hline F03 & $\begin{array}{l}\text { Major Subcontractors provide input to FDH to } \\
\text { support preparation of the Integrated Site } \\
\text { Baseline. }\end{array}$ & $\begin{array}{l}\text { HNF-MP-001, Rev. 1, Management and Integration Plan } \\
\text { HNF-MD-013 Work Breakdown Structure. } \\
\text { HNF-MD-015 Cost Account Plan. } \\
\text { HNF-MD-016 Annual Budget Submittal. } \\
\text { HNF-MD-017 Multi-Year Work Plans. } \\
\text { HNF-MD-019 Project Work Authorization. } \\
\text { HNF-IP-1289 324/327 Bldg. Stabilization/Deactivation Management Plan. }\end{array}$ \\
\hline F04 & $\begin{array}{l}\text { Facility management integrates ES\&H } \\
\text { activities into work planning. }\end{array}$ & $\begin{array}{l}\text { HNF-SP-1234 FSP Multi-Year Work Plan. } \\
\text { HNF-MP-001, Management and Integration Plan. } \\
\text { HNF-MP-005, Risk Management Plan. } \\
\text { HNF-MD-017, Multi-Year Work Plan. }\end{array}$ \\
\hline F05 & $\begin{array}{l}\text { Facility management ensures that ES\&H } \\
\text { resources are budgeted and adequate to } \\
\text { support facility level needs and ES\&H issues. }\end{array}$ & $\begin{array}{l}\text { HNF-MP-013, Work Breakdown Structure. } \\
\text { HNF-MP-001, Management and Integration Plan. } \\
\text { HNF-MD-017, Multi-Year Work Plan. }\end{array}$ \\
\hline F06 & $\begin{array}{l}\text { Major Subcontractors ensure that hazard and } \\
\text { environmental impact identification and } \\
\text { analysis are performed and facility or project } \\
\text { Hazard Classification are identified and } \\
\text { maintained. }\end{array}$ & $\begin{array}{l}\text { HNF-PRO-700, Safety Analysis and Technical Safety Requirements. } \\
\text { HNF-PRO-701, Safety Analysis Process - Existing Facility. } \\
\text { HNF-PRO-062, Identifying and Resolving Unreviewed Safety Questions. } \\
\text { HNF-PRO-452, NEPA, SEPA, Cultural and Natural Resources. } \\
\text { HNF-PRO-079, Pre-Job Safety Planning. } \\
\text { HNF-PRO-074, Safety Responsibilities. } \\
\text { HNF-SD-SPJ-SAR-001, Safety Analysis Report for } 324 \text { BLDG. } \\
\text { HNF-SD-SPJ-SAR-002, } 327 \text { BLDG Safety Analysis Report. } \\
\text { HNF-IP-1264, Section 4.1, Job Control System Implementation } \\
\text { HNF-IP-1264, Section 2.7, Unreviewed Safety Questions HNF-IP-1264, } \\
\text { Section 2.3, Technical Procedure Development and Control. }\end{array}$ \\
\hline
\end{tabular}




\begin{tabular}{|c|c|c|}
\hline NO. & EXPECTATION STATEMENT & IMPLEMENTING DOCUMENTS \\
\hline F07 & $\begin{array}{l}\text { Major Subcontractors manage facility } \\
\text { chemical inventories, and analyze and control } \\
\text { the hazards associated with the inventory. } \\
\text { Chemical materials with no programmatic } \\
\text { needs are excessed or disposed. }\end{array}$ & $\begin{array}{l}\text { HNF-PRO-578, Hazard Communication. } \\
\text { HNF-PRO-699, Storing and Handling Chemicals. } \\
\text { HNF-PRO-079, Pre-Job Safety Planning. } \\
\text { HNF-IP-1264, Section 1.2, Hazard Communication Program: } \\
\text { HNF-PRO-699, Storing and Handling Chemicals. } \\
\text { HNF-IP-1264, Section 6.5, EPCRA Chemical and Material Inventory } \\
\text { HNF-PRO-096, Material Hendling and Storage. } \\
\text { HNF-PRO-335, Use and Control of Purchasing Cand (P-Card). }\end{array}$ \\
\hline F08 & $\begin{array}{l}\text { The Major Subcontractor ensures hazard and } \\
\text { environmental impact identification and } \\
\text { analysis are performed and updated when } \\
\text { facility life cycle and the associated hazards } \\
\text { change. }\end{array}$ & $\begin{array}{l}\text { HNF-PRO-002, Identifying and Resolving Unreviewed Safety Questions } \\
\text { HNF-IP-1264, 2.7, "Unreviewed Safety Questions" } \\
\text { HNF-IP-1264, Section 4.1, "JCS Implementation" } \\
\text { HNF-SD-SPJ-SAR-002, 327 Building Safety Analysis Report } \\
\text { HNF-SD-SPJ-SAR-001, 324 Building Safety Analysis Report } \\
\text { HNF-PRO-568, Environmental Documentation } \\
\text { HNF-PRO-452, NEPA, SEPA, Cultural, and Natural Resources } \\
\text { WHC-SD-NR-ISB-001, Interim Safety Basis for the Fuel Supply Shutdown } \\
\text { Facility } \\
\text { WHC-SD-CP-ISB-003, Interim Safety Basis for the Uranium Trioxide } \\
\text { Powder Storage } \\
\text { FSP-FSS-05-35, Section 01-11, Unreviewed Safety Questions } \\
\text { HNF-IP-1264, Section 6.2, Environmental Screening }\end{array}$ \\
\hline F09 & $\begin{array}{l}\text { Major Subcontractors are responsible for } \\
\text { development of ES\&H goals and objectives } \\
\text { for improving safe operations and } \\
\text { environmental protection. }\end{array}$ & $\begin{array}{l}\text { HNF-POL-POLLU, Pollution Prevention and Waste Minimization Policy. } \\
\text { HNF-PRO-462, Pollution Prevention. } \\
\text { HNF-5053, Environmental, Safety and Health Policy. }\end{array}$ \\
\hline F10 & $\begin{array}{l}\text { Major Subcontractors determine the ES\&H } \\
\text { standards and requirements that apply to a } \\
\text { contracted scope of work and convey them to } \\
\text { lower tiered subcontractors, or other PHMC } \\
\text { Team subcontractors via a contracting/task } \\
\text { order mechanism. }\end{array}$ & $\begin{array}{l}\text { HNF-PRO-078, Subcontractor Safety and Health Management. } \\
\text { FSP-002, Task Order Process. } \\
\text { FSP-004, Subcontractor Safety and Health Oversight. }\end{array}$ \\
\hline F11 & $\begin{array}{l}\text { Major Subcontractors maintain configuration } \\
\text { control of S/RIDs or Requirements Basis } \\
\text { Documents (requirements and implementing } \\
\text { procedures) in accordance with the } \\
\text { Requirements Management Plan. }\end{array}$ & $\begin{array}{l}\text { HNF-PRO-265, Developing and Maintaining S/RIDs } \\
\text { HNF-SD-MP-SRID-008, 324/327 Facilities S/RID. }\end{array}$ \\
\hline F12 & $\begin{array}{l}\text { Major Subcontractors develop and maintain } \\
\text { configuration control of Requirement Basis } \\
\text { Documents and facility-specific implementing } \\
\text { procedures necessary to support compliance } \\
\text { with the applicable ES\&H standards and } \\
\text { requirements relevant to the scope of the work. }\end{array}$ & $\begin{array}{l}\text { HNF-PRO-265, Developing \& Maintaining S/RIDS Procedures. } \\
\text { HNF-SD-MP-SRID-008, 324/327 S/RID. } \\
\text { WHC-SD-NR-ISB-001, Interim Safety Basis for the Fuel Supply Shutdown } \\
\text { Facility } \\
\text { WHC-SD-CP-ISB-003, Interim Safety Basis for the Uranium Trioxide } \\
\text { Powder Storage }\end{array}$ \\
\hline
\end{tabular}




\begin{tabular}{|c|c|c|}
\hline NO. & EXPECTATION STATEMENT & IMPLEMENTING DOCUMENTS \\
\hline F13 & $\begin{array}{l}\text { Major Subcontractors ensure that Enterprise, } \\
\text { Infrastructure and lower tiered subcontractors } \\
\text { comply with the FDH and facility-specific } \\
\text { implementing procedures applicable to the } \\
\text { contracted scope of work. }\end{array}$ & $\begin{array}{l}\text { HNF-PRO-186, Preparing a Statement of Work for Services } \\
\text { FSP-002, Task Order Process } \\
\text { FSP-004, Subcontractor Safety and Health Oversight } \\
\text { HNF-PRO-422, Invoice Approval. } \\
\text { HNF-IP-1264, Section 4.1, Job Control System Implementation. }\end{array}$ \\
\hline F14 & $\begin{array}{l}\text { Major Subcontractors develop implementing } \\
\text { procedures not contained in the FDH Policies } \\
\text { and Procedures System but determined } \\
\text { necessary to support effective implementation } \\
\text { of the facility requirements basis. }\end{array}$ & $\begin{array}{l}\text { HNF-IP-1264, Section 2.10, Management Assessment Program. } \\
\text { HNF-IP-1264, Section 2.6, Corrective Action Management. }\end{array}$ \\
\hline F15 & $\begin{array}{l}\text { Major Subcontractors, as directed by FDH } \\
\text { Project Direction, develop (or document } \\
\text { exception to) a SAR for Nuclear facilities. }\end{array}$ & $\begin{array}{l}\text { HNF-IP-1264, Section 2.7, "Unreviewed Safety Questions". } \\
\text { HNF-SD-SPJ-SAR-002, 327 Building Safety Analysis Report. } \\
\text { HNF-SD-SPJ-SAR-001, 324 Building Safety Analysis Report. } \\
\text { WHC-SD-NR-ISB-001, Interim Safety Basis for the Fuel Supply Shutdown } \\
\text { Facility } \\
\text { WHC-SD-CP-ISB-003, Interim Safety Basis for the Uranium Trioxide } \\
\text { Powder Storage }\end{array}$ \\
\hline F16 & $\begin{array}{l}\text { Major Subcontractors, as directed by FDH } \\
\text { Project Direction, develop (or document } \\
\text { exception to) an ASA for each radiological, } \\
\text { and non-nuclear facility. }\end{array}$ & $\begin{array}{l}\text { WHC-SD-NR-ISB-001, Interim Safety Basis for the Fuel Supply Shutdown } \\
\text { Facility } \\
\text { WHC-SD-CP-ISB-003, Interim Safety Basis for the Uranium Trioxide } \\
\text { Powder Storage } \\
\text { FSP-FSS-5-35, Section 01-11, Unreviewed Safety Questions }\end{array}$ \\
\hline F17 & $\begin{array}{l}\text { Major Subcontractors operate industrial } \\
\text { facilities in compliance with applicable } \\
\text { operating procedures, permits, and consent } \\
\text { orders and agreements (e.g., Tri-Party } \\
\text { Agreement). If hazard and environmental } \\
\text { impact analyses results indicate a potential for } \\
\text { non-compliance, Major Subcontractors notify } \\
\text { FDH Project Direction and ES\&H of the } \\
\text { potential non-compliance. }\end{array}$ & $\begin{array}{l}\text { Note: The } 300 \text { Area Facilities are covered under nuclear and radiological } \\
\text { facilities. }\end{array}$ \\
\hline F18 & $\begin{array}{l}\text { Major Subcontractors ensure that personnel } \\
\text { performing hazard identification and analysis } \\
\text { and development of controls are qualified and } \\
\text { trained per the FDH Qualification and } \\
\text { Training Plan (HNF-MP-011) to perform the } \\
\text { task safely, completely and effectively. }\end{array}$ & $\begin{array}{l}\text { HNF-MP-011, Sitewide Qualification and Training Plan } \\
\text { HNF-IP-1264, Section 2.16, Facility Worker Training. } \\
\text { HNF-PRO-168, Employee Training } \\
\text { FSP-FSS-05-35, Section 05-02, Training Plan }\end{array}$ \\
\hline F19 & $\begin{array}{l}\text { The Major Subcontractor facility and project } \\
\text { managers implement the automated JHA } \\
\text { process to support facility work activities and } \\
\text { meet ISMS Activity Level Expectations. }\end{array}$ & $\begin{array}{l}\text { HNF-PRO-079, Pre-Job Safety Planning. } \\
\text { HNF-IP-1264, Section 2.3; Technical Procedure Development and Control. } \\
\text { HNF-IP-1264, Section 4.1, Job Control System Implementation. } \\
\text { SI-300 Area-025, Automated Job Hazard Analysis } \\
\text { FSP-FSS-05-35, Section 02-01, Job Control System }\end{array}$ \\
\hline
\end{tabular}




\begin{tabular}{|c|c|c|}
\hline NO. & EXPECTATION STATEMENT & IMPLEMENTING DOCUMENTS \\
\hline $\mathbf{F} 20$ & $\begin{array}{l}\text { The Major Subcontractor defines job hazard } \\
\text { analysis requirements for lower tiered } \\
\text { subcontractors to ensure that all work } \\
\text { activities are performed safely and in } \\
\text { accordance with the applicable PHMC Team } \\
\text { standards, requirements, and implementing } \\
\text { procedures. }\end{array}$ & $\begin{array}{l}\text { HNF-PRO-078, Subcontractor Safety \& Health Management. } \\
\text { HNF-PRO-079, Pre-Job Safety Planning. } \\
\text { FSP-004, Subcontrector Safety \& Health Oversight. } \\
\text { HNF-IP-1264, Section 2.3, 24/327 Technical Procedure Development \& } \\
\text { Control. } \\
\text { HNF-IP-1264, Section 4.1, 324/327 Job Control. } \\
\text { SI-300 Area-025, Automated Job Hazard Analysis } \\
\text { FSP-FSS-05-35, Section 02-01, Job Control System }\end{array}$ \\
\hline F21 & $\begin{array}{l}\text { Major Subcontractor facility managers } \\
\text { implement a team approach to work planning. }\end{array}$ & $\begin{array}{l}\text { HNF-IP-1264, Section 4.1, Job Control Implementation. } \\
\text { SI-300 Area-025, Automated Job Hazard Analysis } \\
\text { FSP-FSS-05-35, Section 02-01, Job Control System }\end{array}$ \\
\hline $\mathbf{F 2 2}$ & $\begin{array}{l}\text { Major Subcontractor facility managers } \\
\text { develop expectations and performance } \\
\text { measures for the work planning process to } \\
\text { document improvements made through ISMS } \\
\text { implementation. }\end{array}$ & SI-300 Area-027, ISMS Performance Measures \\
\hline F23 & $\begin{array}{l}\text { Major Subcontractors develop and maintain a } \\
\text { graded approach to work planning based on } \\
\text { risk, complexity, and routine versus non- } \\
\text { routine nature of work activities. }\end{array}$ & $\begin{array}{l}\text { HNF-IP-1264, Section 2.3, Technical Procedure Development and Control. } \\
\text { HNF-IP-1264, Section 4.1, Job Control System Implementation. } \\
\text { HNF-IP-1277, Section 3.1.1, } 300 \text { Area Enhanced Radiological Work } \\
\text { Planning. } \\
\text { SI-300 Area-025, Automated Job Hazard Analysis } \\
\text { FSP-FSS-05-35, Section 02-01, Job Control System }\end{array}$ \\
\hline $\mathbf{F} 24$ & $\begin{array}{l}\text { Major Subcontractors develop a graded } \\
\text { method to authorize work to be performed } \\
\text { within their facilities. }\end{array}$ & $\begin{array}{l}\text { HNF-PRO-069, Maintenance Management. } \\
\text { HNF-IP-1264, Section 4.1, Job Control System Implementation. } \\
\text { FSP-FSS-05-35, Section 02-01, Job Control System }\end{array}$ \\
\hline F25 & $\begin{array}{l}\text { Facility managers will implement appropriate } \\
\text { FDH (ES\&H) implementing procedures } \\
\text { (Appendix B, Table B-2) based on facility } \\
\text { hazards, environmental impacts, and } \\
\text { operations. }\end{array}$ & $\begin{array}{l}\text { HNF-PRO-265, Developing and Maintaining S/RIDs. } \\
\text { HNF-SD-MP-008, 324/327 Facilities S/RID }\end{array}$ \\
\hline F26 & $\begin{array}{l}\text { The Major Subcontractors develop, maintain, } \\
\text { and implement TSRs, OSRs, and } \\
\text { environmental permits and other lower tiered } \\
\text { and defense-in-depth controls as appropriate. }\end{array}$ & $\begin{array}{l}\text { HNF-SD-SPJ-SAR-001, } 324 \text { Building Safety Analysis Report. } \\
\text { HNF-SD-SPJ-OSR-001, Operational Safety Requirements for the } 324 \\
\text { Facility. } \\
\text { HNF-SD-SPJ-SAR-002, } 327 \text { Building Safety Analysis Report. } \\
\text { HNF-SD-SPJ-OSR-002, Operational Safety Requirements for the } 327 \\
\text { Facility. } \\
\text { WHC-SD-NR-ISB-001, Interim Safety Basis for the Fuel Supply Shutdown } \\
\text { Facility } \\
\text { WHC-SD-CP-ISB-003, Interim Safety Basis for the Uranium Trioxide } \\
\text { Powder Storage } \\
\text { HNF-IP-1264, Section 2.23, 324/327 Facilities OSR Overview Program. } \\
\text { HNF-IP-1264, Section 2.7, Unreviewed Safety Questions. } \\
\text { FSP-FSS-05-35, Section 01-11, Unreviewed Safety Questions }\end{array}$ \\
\hline
\end{tabular}




\begin{tabular}{|c|c|c|}
\hline NO. & EXPECTATION STATEMENT & IMPLEMENTING DOCUMENTS \\
\hline F27 & $\begin{array}{l}\text { The Major Subcontractors ensure involvement } \\
\text { of the appropriate ES\&H personnel and } \\
\text { workers during the development of controls. }\end{array}$ & $\begin{array}{l}\text { HNF-PRO-079, "Pre-Job Safety Planning". } \\
\text { HNF-IP-1264 Section 4.1, "Job Control System Implementation". } \\
\text { HNF-IP-1264, Section 2.3, Technical Procedure Development and Control } \\
\text { FSP-FSS-05-35, Section 02-01, Job Control System } \\
\text { SI-300 Area-025, Automated Job Hazard Analysis }\end{array}$ \\
\hline F28 & $\begin{array}{l}\text { Work planning teams ensure that planned } \\
\text { work activities can be conducted within the } \\
\text { controls specified (TSRs/OSRs for nuclear } \\
\text { facilities) by facility hazard analysis and } \\
\text { environmental documentation. }\end{array}$ & $\begin{array}{l}\text { HNF-IP-1264 Section 4.1, Job Control System Implementation. } \\
\text { SI-300 Area-025, Automated Job Hazard Analysis } \\
\text { HNF-IP-1264, Section 2.23, 324/327 Facilities OSR Overview Program. } \\
\text { FSP-FSS-05-35, Section 02-01, Job Control System. }\end{array}$ \\
\hline F29 & $\begin{array}{l}\text { Major Subcontractors periodically review } \\
\text { Facility Emergency Action Levels to } \\
\text { determine the accuracy of established } \\
\text { emergency event classifications based on } \\
\text { changing facility mission and life cycle. }\end{array}$ & $\begin{array}{l}\text { HNF-PRO-424, Maintaining Facility Emergency Preparedness. } \\
\text { HNF-IP-1270, (324 facility), Emergency Response Guides. } \\
\text { HNF-IP-2355, (327 facility), Emergency Response Guides. } \\
\text { HNF-IP-0263-324, Building Emergency Plan for 324. } \\
\text { HNF-IP-0263-327, Building Emergency Plan for 327. } \\
\text { HNF-IP-1264, Section 1.6, Emergency/Operational Drill Program. }\end{array}$ \\
\hline F30 & $\begin{array}{l}\text { Facility Managers periodically conduct drills } \\
\text { in accordance to the Hanford Site Emergency } \\
\text { Management Program. }\end{array}$ & $\begin{array}{l}\text { HNF-PRO-424, Maintaining Facility Emergency } \\
\text { HNF-PRO-056, Drill Program Policy } \\
\text { HNF-PRO-1264, 1.6 Emergency/Operational Drill Program. }\end{array}$ \\
\hline F31 & $\begin{array}{l}\text { Facility hazards and environmental impacts } \\
\text { created by changing conditions (e.g., mission, } \\
\text { life cycle, operations, etc.) are analyzed to } \\
\text { ensure potentially hazardous and } \\
\text { environmental impact conditions are identified } \\
\text { and proper controls established. }\end{array}$ & $\begin{array}{l}\text { HNF-PRO-079, Pre-job Safety Planning. } \\
\text { SI-300 Area-025, Automated Job Hazard Analysis } \\
\text { HNF-IP-1277, section 3.1.1, } 300 \text { Area Enhanced Radiological Work } \\
\text { Planning. } \\
\text { HNF-PRO-1264, Section 4.1, Job Control System Implementation. } \\
\text { HNF-PRO-1264, Section 2.3, Technical Procedure Development and } \\
\text { Control. } \\
\text { HNF-PRO-062, Identifying/Resolving Unreviewed Safety Questions. } \\
\text { HNF-IP-1264, Section 2.7, Unreviewed Safety Questions. } \\
\text { HNF-SD-SPJ-SAR-001, 324 SAR. } \\
\text { HNF-SD-SPJ-SAR-002, 327 SAR. } \\
\text { WHC-SD-NR-ISB-001, Interim Safety Basis for the Fuel Supply Shutdown } \\
\text { Facility } \\
\text { WHC-SD-CP-ISB-003, Interim Safety Basis for the Uranium Trioxide } \\
\text { Powder Storage } \\
\text { FSP-FSS-05-35, Section 01-11, Unreviewed Safety Questions } \\
\text { FSP-FSS-05-35, Section 02-01, Job Control System }\end{array}$ \\
\hline F32 & $\begin{array}{l}\text { Immediate response to events / occurrences } \\
\text { during work activities that cause emergency } \\
\text { response actions to be initiated are consistent } \\
\text { with facility emergency response guidelines. }\end{array}$ & $\begin{array}{l}\text { HNF-PRO-1270, Emergency Response Guides (324). } \\
\text { HNF-PRO-2355, Emergency Response Guides (327). } \\
\text { HNF-PRO-0263-324, Building Emergency Plan. } \\
\text { HNF-PRO-0263-327, Building Emergency Plan. } \\
\text { HNF-IP-1264 Section 1.6, Emergency/Operational Drill Program }\end{array}$ \\
\hline F33 & $\begin{array}{l}\text { The Major Subcontractors document and } \\
\text { maintain their Authorization Envelopes. }\end{array}$ & $\begin{array}{l}\text { HNF-SD-MP-SRID-008, 324/327 S/RID } \\
\text { HNF-PRO-AE, DRAFT, Authorization Envelope. }\end{array}$ \\
\hline
\end{tabular}




\begin{tabular}{|c|c|c|}
\hline NO. & EXPECTATION STATEMENT & IMPLEMENTING DOCUMENTS \\
\hline F34 & $\begin{array}{l}\text { Major Subcontractors convey through a } \\
\text { contract mechanism (e.g., subcontract, task } \\
\text { order) the parameters of their Authorization } \\
\text { Envelope and work within these parameters } \\
\text { regardless of the performer of the work. }\end{array}$ & $\begin{array}{l}\text { HNF-PRO-186, Preparing a Statement of Work for Services. } \\
\text { HNF-IP-1264 Section 2.7, Unreviewed Safety Questions. } \\
\text { HNF-PRO-552, Project Control. } \\
\text { HNF-PRO-565, Statement of Work, Architect-Engineer. } \\
\text { HNF-SD-SPJ-SAR-001, } 324 \text { SAR. } \\
\text { HNF-SD-SPJ-SAR-002, 327 SAR. } \\
\text { WHC-SD-NR-ISB-001, Interim Safety Basis for the Fuel Supply Shutdown } \\
\text { Facility } \\
\text { WHC-SD-CP-ISB-003, Interim Safety Basis for the Uranium Trioxide } \\
\text { Powder Storage } \\
\text { FSP-FSS-05-35, Section 01-11, Unreviewed Safety Questions }\end{array}$ \\
\hline F35 & $\begin{array}{l}\text { Major Subcontractors maintain change control } \\
\text { and configuration control procedures to ensure } \\
\text { that work execution is within the authorization } \\
\text { envelope. }\end{array}$ & $\begin{array}{l}\text { HNF-PRO-440, "Engineering Document Change Control". } \\
\text { HNF-MP-013, PHMC "Configuration Management Plan". } \\
\text { SI-300 Area-007, "Approval Designators and Safety Class". } \\
\text { HNF-IP-1264, Section 2.7, "Unreviewed Safety Questions". } \\
\text { HNF-PRO-062, "Identifying and Resolving USQs". } \\
\text { FSP-FSS-5-35, Section 01-11, Unreviewed Safety Questions }\end{array}$ \\
\hline F36 & $\begin{array}{l}\text { Major Subcontractors implement requirements } \\
\text { and controls in accordance with the facility } \\
\text { authorization envelope and JHA. }\end{array}$ & $\begin{array}{l}\text { HNF-IP-1277, Section 3.1.1, } 300 \text { Area Enhanced Radiological Work } \\
\text { Planning. } \\
\text { FSP-004, Subcontractor Safety and Health Oversight. } \\
\text { HNF-PRO-079, Pre-Job Planning. } \\
\text { SI-300 Area-025, Automated Job Hazard Analysis } \\
\text { HNF-IP-1264 Section 2.7, Unreviewed Safety Questions } \\
\text { HNF-IP-1264 Section 2.3, Technical Procedure Development/Control. } \\
\text { HNF-IP-1264 Section 4.1, Job Control System Implementation. } \\
\text { FSP-FSS-5-35, Section 02-01, Job Control System } \\
\text { HNF-SD-SPJ-OSR-001, 327 Operational Safety Requirements. } \\
\text { HNF-SD-SPJ-SAR-001, 327 Safety Analysis Report. } \\
\text { HNF-SD-SPJ-OSR-001, 327 Operational Safety Requirements. } \\
\text { HNF-SD-SPJ-SAR-001, 327 Safety Analysis Report. } \\
\text { WHC-SD-NR-ISB-001, Interim Safety Basis for the Fuel Supply Shutdown } \\
\text { Facility } \\
\text { WHC-SD-CP-ISB-003, Interim Safety Basis for the Uranium Trioxide } \\
\text { Powder Storage } \\
\text { FSP-FSS-5-35, Section 01-11, Unreviewed Safety Questions }\end{array}$ \\
\hline F37 & $\begin{array}{l}\text { Major Subcontractors ensure that the } \\
\text { appropriate environmental permits are } \\
\text { prepared and that facility operations are } \\
\text { maintained in accordance with the } \\
\text { requirements of these documents. }\end{array}$ & $\begin{array}{l}\text { HNF-IP-1264, Section 2.3, Technical Procedure Development and Control. } \\
\text { HNF-IP-1264, Section 4.1, Rev. 2, Job Control System Implementation. } \\
\text { HNF-IP-1264, Section 6.2, Environmental Compliance Screening } \\
\text { HNF-SD-SPJ-SAR-001, } 324 \text { Building Safety Analysis Report, Revision } 0 . \\
\text { HNF-SD-SPJ-SAR-002, } 327 \text { Building Safety Analysis Report, Revision 0. } \\
\text { WHC-SD-NR-ISB-001, Interim Safety Basis for the Fuel Supply Shutdown } \\
\text { Facility } \\
\text { WHC-SD-CP-ISB-003, Interim Safety Basis for the Uranium Trioxide } \\
\text { Powder Storage }\end{array}$ \\
\hline
\end{tabular}




\begin{tabular}{|c|c|c|}
\hline NO. & EXPECTATION STATEMENT & IMPLEMENTING DOCUMENTS \\
\hline F38 & $\begin{array}{l}\text { The Major Subcontractor managers specify the } \\
\text { appropriate training and qualification in the } \\
\text { Training Implementation Matrices and } \\
\text { Training Matrix and ensure that employees } \\
\text { attend the required training and qualification } \\
\text { classes. }\end{array}$ & $\begin{array}{l}\text { HNF-IP-1264, Section 2.16, Facility Worker Training. } \\
\text { HNF-IP-1281, } 300 \text { Area Stabilization Projects Training Plan. } \\
\text { FSP-FSS-5-35, Section 05-02, Training Plan }\end{array}$ \\
\hline F39 & $\begin{array}{l}\text { Major Subcontractors ensure that all personnel } \\
\text { working on a project or at a facility are } \\
\text { qualified and trained to conduct the work } \\
\text { scope in a safe, environmentally protective, } \\
\text { and efficient manner. }\end{array}$ & $\begin{array}{l}\text { HNF-IP-1184, Training Requirements and Instructions, Mandated/Directed } \\
\text { Training Requirement Summaries. } \\
\text { HNF-IP-1264, Section 2.16, Facility Worker Training } \\
\text { FSP-FSS-5-35, Section 05-02, Training Plan }\end{array}$ \\
\hline $\mathbf{F 4 0}$ & $\begin{array}{l}\text { Major Subcontractor managers complete an } \\
\text { EJTA for each of their employees, as specified } \\
\text { by the FDH and DOE-RL HOHP directive. }\end{array}$ & HNF-PRO-111, "Occupational Medical Qualification and Monitoring". \\
\hline F41 & $\begin{array}{l}\text { Major Subcontractor facility or project } \\
\text { manager ensures the completion of EJTAs for } \\
\text { all lower tiered subcontractor employees who } \\
\text { will perform work within the Major } \\
\text { Subcontractor managed or operated facility or } \\
\text { project and as specified by the DOE-RL } \\
\text { HOHP directive. }\end{array}$ & $\begin{array}{l}\text { HNF-PRO-111, Occupational Medical Qualification and Monitoring. } \\
\text { BWHC-FSP-004, Subcontractor Safety and Health Oversight. }\end{array}$ \\
\hline F42 & $\begin{array}{l}\text { The Major Subcontractors assess the adequacy } \\
\text { of hazard controls when medical monitoring } \\
\text { results indicate adverse health consequences to } \\
\text { workers as a result of work place hazards. }\end{array}$ & $\begin{array}{l}\text { HNF-PRO-111, Occupational Medical Surveillance and Monitoring. } \\
\text { HNF-PRO-409 "Exposure Monitoring, Reporting, and Exposure Records } \\
\text { Management". } \\
\text { HNF-IP-1264, Section 1.2, "Hazard Communication Program". } \\
\text { FSP-FSS-05-35, Section 01-13, Hazard Communication Control Program }\end{array}$ \\
\hline F43 & $\begin{array}{l}\text { The Major Subcontractors conduct } \\
\text { Operational Readiness Reviews and Readiness } \\
\text { Assessments as required. }\end{array}$ & $\begin{array}{l}\text { HNF-PRO-055, Startup and Restart of Facilities. } \\
\text { HNF-SD-MP-SRID-008, 324/327 S/RID }\end{array}$ \\
\hline F44 & $\begin{array}{l}\text { Major Subcontractors establish and maintain } \\
\text { procedures for conducting pre-job briefings. }\end{array}$ & $\begin{array}{l}\text { HNF-PRO-079, Pre-Job Safety Planning } \\
\text { SI-300 Area-025, Automated Job hazard Analysis }\end{array}$ \\
\hline F45 & $\begin{array}{l}\text { Major Subcontractors evaluate work to be } \\
\text { conducted in a nuclear facility against its } \\
\text { approved authorization basis and conduct USQ } \\
\text { screenings as necessary. }\end{array}$ & $\begin{array}{l}\text { HNF-PRO-062, Identifying and Resolving Unreviewed Safety Questions. } \\
\text { HNF-IP-1264, Section 2.2, "Administrative Procedure Development and } \\
\text { Control," } \\
\text { HNF-IP-1264, Section 2.3, "Technical Procedure Development and } \\
\text { Control," } \\
\text { HNF-IP-1264, Section 2.7, "Unreviewed Safety Question," } \\
\text { HNF-IP-1264, Section 2.8, "Plant Review Committee," } \\
\text { HNF-IP-1264, Section 4.1, Job Control System Implementation". } \\
\text { FSP-FSS-05-35, Section 01-11, Unreviewed safety Questions } \\
\text { FSP-FSS-05-35, Section 02-01, Job Control System }\end{array}$ \\
\hline
\end{tabular}




\begin{tabular}{|c|c|c|}
\hline NO. & EXPECTATION STATEMENT & IMPLEMENTING DOCUMENTS \\
\hline F46 & $\begin{array}{l}\text { Major Subcontractors evaluate work to be } \\
\text { conducted against its approved Authorization } \\
\text { Envelope (including consent orders and } \\
\text { agreements, permits, and other documents). }\end{array}$ & $\begin{array}{l}\text { HNF-PRO-233, Review and Approval of Documents. } \\
\text { SI-300 Area-007, Approval Description and Safety Class. } \\
\text { HNF-IP-1264, Section 2.7; Unreviewed Safety Questions. } \\
\text { HNF-IP-1264, Section 4.1; Job Control System Implementation. } \\
\text { FSP-FSS-05-35, Section 01-11, Unreviewed Safety Questions } \\
\text { FSP-FSS-05-35, Section 02-01, Job Control System } \\
\text { SI-300 Area-025, Automated Job Hazard Analysis }\end{array}$ \\
\hline F47 & $\begin{array}{l}\text { Major Subcontractors ensure that personnel } \\
\text { evaluating USQ's are trained and qualified to } \\
\text { perform the evaluation. }\end{array}$ & $\begin{array}{l}\text { HNF-PRO-062, Identifying and Resolving Unreviewed Safety Questions. } \\
\text { HNF-IP-1281, } 300 \text { Area Stabilization Projects Training Plan. } \\
\text { HNF-IP-1264, Section 2.7, Unreviewed Safety Questions. } \\
\text { FSP-FSS-05-35, Section 01-11, Unreviewed Safety Questions } \\
\text { FSP-FSS-05-35, Section 05-02, Training Plan }\end{array}$ \\
\hline F48 & $\begin{array}{l}\text { Line managers and supervisors conduct work } \\
\text { area assessments and monitor safety and } \\
\text { environmental protection by routinely } \\
\text { observing work activities to identify and } \\
\text { correct deficiencies. Management is present } \\
\text { during performance of high hazard tasks. } \\
\text { These activities include coaching employees } \\
\text { as necessary to make process improvements. }\end{array}$ & $\begin{array}{l}\text { HNF-PRO-074, Safety Responsibilities. } \\
\text { HNF-IP-1264, Section 2.10, Management Assessment Program. } \\
\text { SI-300 Area-014, } 300 \text { Area Stabilization project Organizational Structure } \\
\text { FSP-FSS-05-35, Section 01-16, Management Self Assessment }\end{array}$ \\
\hline F49 & $\begin{array}{l}\text { Major Subcontractors establish leading } \\
\text { indicators directly relevant to safe } \\
\text { environmentally protective work performance. }\end{array}$ & $\begin{array}{l}\text { HNF-MP-599, Project Hanford Quality Assurance Program. } \\
\text { HNF-IP-1264 Section 2.6, Corrective Action Management. } \\
\text { HNF-IP-1264 Section 2.10, Management Assessment Program. } \\
\text { FSP-FSS-05-35, Section 01-16, Management Self Assessment }\end{array}$ \\
\hline F50 & $\begin{array}{l}\text { Major Subcontractors develop a schedule for } \\
\text { facility or project implementation of ISMS } \\
\text { Expectations and track performance. }\end{array}$ & \\
\hline F51 & $\begin{array}{l}\text { Major Subcontractors identify results from } \\
\text { occurrence reports and various types of } \\
\text { accident investigations to determine the direct } \\
\text { contributing, and root causes of incidents, and } \\
\text { use the results in establishing Lessons } \\
\text { Learned. }\end{array}$ & $\begin{array}{l}\text { HNF-PRO-052, Corrective Action Management. } \\
\text { HNF-PRO-058, Critique Procedure. } \\
\text { HNF-PRO-060, Reporting Occurrences and Processing Operations } \\
\text { Information. } \\
\text { HNF-IP-1264, Section 2.22, Occurrence Categorization, Notification, and } \\
\text { Reporting. } \\
\text { FSP-FSS-05-35, Section 06-02, Occurrence Categorization, Notification and } \\
\text { Reporting }\end{array}$ \\
\hline F52 & $\begin{array}{l}\text { Major Subcontractors implement the } \\
\text { automated JHA post-job review feature and } \\
\text { maintain information from the review in the } \\
\text { automated system. }\end{array}$ & SI-300 Area-025, Automated Job Hazard Analysis \\
\hline F53 & $\begin{array}{l}\text { Major Subcontractors monitor and oversee } \\
\text { operations and activities that pose a significant } \\
\text { safety hazard or a significant impact to the } \\
\text { environment. }\end{array}$ & $\begin{array}{l}\text { HNF-IP-1264, Section 2.10, Management Assessment Program } \\
\text { FSP-FSS-05-35, Section 01-16, Management Self Assessment } \\
\text { SI-300 Area-020, Personnel Authorized to Control Work in the Field } \\
\text { HNF-IP-1264, Section 4.4, Supervision of Field Work Activities } \\
\text { FSP-FSS-05-35, Section 02-02, Supervision of Field Work Activities }\end{array}$ \\
\hline
\end{tabular}




\begin{tabular}{|c|c|c|}
\hline No. & EXPECTATION STATEMENT & IMPLEMENTING DOCUMENTS \\
\hline F54 & $\begin{array}{l}\text { Major Subcontractors evaluate ES\&H } \\
\text { compliance performance indicators to provide } \\
\text { feedback and information for continuous } \\
\text { improvement. }\end{array}$ & $\begin{array}{l}\text { HNF-PRO-052, "Corrective Action Management". } \\
\text { HNF-IP-1264, Section 2.10, "Management Assessment Program". } \\
\text { FSP-FSS-05-35, Section 01-16, Management Self Assessment }\end{array}$ \\
\hline F55 & $\begin{array}{l}\text { Major Subcontractors implement management } \\
\text { assessment program in accordance with the } \\
\text { FDH Quality Assurance Program. }\end{array}$ & $\begin{array}{l}\text { HNF-PRO-246, Management Assessment. } \\
\text { HNF-IP-1264, 2.10, Management Assessment Program } \\
\text { FSP-FSS-05-35, Section 01-16, Management Self Assessment }\end{array}$ \\
\hline F56 & $\begin{array}{l}\text { Major Subcontractors that use other } \\
\text { subcontractors (e.g. Numatec, FDNW) to } \\
\text { perform project or construction management } \\
\text { services, that include oversight and } \\
\text { compliance to ES\&H requirements and } \\
\text { implementing procedures assess the } \\
\text { performance of these subcontractors. }\end{array}$ & $\begin{array}{l}\text { HNF-PRO-078, Subcontractor Safety and Health Management } \\
\text { FSP-004, Subcontractor Safety and Health Oversight. }\end{array}$ \\
\hline F57 & $\begin{array}{l}\text { Major Subcontractor facility managers report } \\
\text { unsafe and environmentally unsound acts and } \\
\text { conditions within the facility and review these } \\
\text { findings as opportunities to improve. }\end{array}$ & $\begin{array}{l}\text { HNF-IP-1264 Section 2.10, Management Assessment Program. } \\
\text { HNF-IP-1264 Section 2.22, Occurrence Categorization, Notification and } \\
\text { Reporting. } \\
\text { HNF-IP-052, Corrective Action Management. } \\
\text { FSP-FSS-05-35, Section 01-16, Management Self Assessment } \\
\text { FSP-FSS-05-35, Section 06-02, Occurrence Categorization, Notification and } \\
\text { Reporting }\end{array}$ \\
\hline F58 & $\begin{array}{l}\text { Major Subcontractors resolve adverse } \\
\text { performance indicator trends based on } \\
\text { organizational priorities and management } \\
\text { direction. }\end{array}$ & HNF-PRO-052, Corrective Action Management \\
\hline F59 & $\begin{array}{l}\text { Facility line managers review performance } \\
\text { indicators routinely to determine potential } \\
\text { safety and environmental performance } \\
\text { improvements in work practices and } \\
\text { processes. }\end{array}$ & $\begin{array}{l}\text { HNF-MD-018, Performance Reporting. } \\
\text { HNF-IP-1264, Section 2.10, Management Assessment Program. } \\
\text { HNF-MP-599, Project Hanford Quality Assurance Program Description. } \\
\text { FSP-FSS-05-35, Section 01-16, Management Self Assessment }\end{array}$ \\
\hline F60 & $\begin{array}{l}\text { Major Subcontractors conform with FDH } \\
\text { plans and procedures to ensure safe work } \\
\text { performance that protects the worker, the } \\
\text { public, and the environment. }\end{array}$ & $\begin{array}{l}\text { PHMC Contract, Part 1, Section H, Clause H.14, "Laws, Regulations, and } \\
\text { DOE Directives". } \\
\text { HNF-MP-001, Management and Integration Plan, Section 1.5, "Document } \\
\text { Hierarchy". } \\
\text { BWHC-MD-010, "Procedure Compliance - In Intent and Action". } \\
\text { HNF-IP-1264, Section 2.2, Administrative Procedure Development and } \\
\text { Control". } \\
\text { HNF-IP-1264, Section 2.3, Technical Procedure Development and Control". }\end{array}$ \\
\hline
\end{tabular}


HNF-5220

300 AREA FACILITY STABILIZATION PROJECT

Effective Date $9 / 30 / 99$

Page 20 of 21

\begin{tabular}{|c|l|l|}
\hline NO. & \multicolumn{1}{|c|}{ EXPECTATION STATEMENT } & \multicolumn{1}{|c|}{ IMPLEMENTING DOCUMENTS } \\
\hline F61 & $\begin{array}{l}\text { Major Subcontractors establish reward and } \\
\text { recognition programs to promote safe behavior } \\
\text { that is safe, protects the environment, and } \\
\text { reflects company values. (F61) }\end{array}$ & FSP-003, Corporate Employee Recognition Funds \\
\hline F62 & $\begin{array}{l}\text { Major Subcontractor senior management } \\
\text { participate in ISMS reviews, review } \\
\text { assessment results, and directs corrective } \\
\text { actions/improvements. }\end{array}$ & $\begin{array}{l}\text { HNF-IP-1264, Section 2.6, “Corrective Action Management." } \\
\text { HNF-IP-1264, Section 2.10, "Management Assessment Program." }\end{array}$ \\
\hline
\end{tabular}




\section{TABLE 2}

\begin{tabular}{|c|c|}
\hline & ACTIVITY LEVEL EXPECTATION STATEMENTS \\
\hline Al & Employees are familiar with the ES\&H policy and perform work consintent with the policy. \\
\hline A2 & Individual workers assint in the work planning and hezard identification and analyais process. \\
\hline A3 & Work planning teams develop and document an agreed-upon set of controls adequate to mitigate the identified hazard(s) and environmental impacts. \\
\hline A4 & Work plaming teams evaluate whether existing/proposed controls for a given hazard or environmentsl impact generate a new, different hezard or impact. \\
\hline As & $\begin{array}{l}\text { Work plaming teams effectively communicate the identified hazards and environmental impacts and apecifiod controls to all personnel performing the } \\
\text { work activity. }\end{array}$ \\
\hline A6 & $\begin{array}{l}\text { Tasks which have the potential for challenging the facility Authorization Envelope or cause environmental impacts are identified as part of the work } \\
\text { planning process. }\end{array}$ \\
\hline A7 & $\begin{array}{l}\text { Pro-job briefing discuss work hazards and environmental impacts based on the task to be performed and facility conditions, plus omergency contingency } \\
\text { actions and worker responibilities during an emargency. }\end{array}$ \\
\hline A8 & Work Superviars and work teams conduct face-to-face pre-job briefings prior to the performance of work \\
\hline A9 & Work Supervisors utilize the AJHA as the basis for the pre-job briefing which incorporates the ISMS Core Functions. \\
\hline Al0 & $\begin{array}{l}\text { Work Supervisor ensures that the work instructions, work procedures, standerd operating procedures, etc. deacribing how the work is to be performed are } \\
\text { adequately conveyed to all workers repardless of when they join the work team. }\end{array}$ \\
\hline Al1 & $\begin{array}{l}\text { Work Supervisor inoorporates ES\&H requirements, implementing procedures, and permits (e.g., confined space, radiological work, etc) into individual } \\
\text { work activities. }\end{array}$ \\
\hline A12 & $\begin{array}{l}\text { Wark Supervisor ensures that the balanced combination of craft akills/worksite aupervision, and documentation is in place at work startup and } \\
\text { throughout the activity. }\end{array}$ \\
\hline A13 & Work Supervisor ensures that the controls required by the JHA are in plece before the work activity is initiated. \\
\hline A14 & Work Supervinor ensures that the required approvals and permits heve been obtained prior to the work activity being initiated. \\
\hline A15 & Individual Workers successfully complete training courses as required by the worker's training matrix. \\
\hline A16 & Work Supervieor maintains configuration control of drawings and documents associated with the work activity. \\
\hline Al7 & Work place anfoty isaues are identified and addressed by firat line manegementapervision for resolution. \\
\hline A18 & Individual workers perform the work activity in accordance with the specified work instructions, work procedures, standard operating procedures, ete. \\
\hline Al9 & $\begin{array}{l}\text { Individual workers maintain a questioning attitude and use "STOP WORK" authority if the work inatructiona, work procedures, standard operating } \\
\text { procedures are unclear or inadequate and pose a hazard to the worker, the public, or the environment. }\end{array}$ \\
\hline A20 & $\begin{array}{l}\text { Individual workers use and recommend changes to work indructions, hazard and environmental controls, and the work planning process based on actual } \\
\text { and evolving field conditions. }\end{array}$ \\
\hline A21 & Individual workers comply with ES\&H standerds and requirements implementing procedures. \\
\hline A22 & Individual workers conduct work in accordance with the controls (engineering, administrative and personal protective equipment) specifiod in the JHA. \\
\hline A23 & Individual workers obey postings, warning signs, etc. \\
\hline A24 & $\begin{array}{l}\text { Individual workers communicate any safety or environmental concerns to their manager. Individual workers promptly report all aocidents, near misses, } \\
\text { non-compliances, occupational injuries or illnesses, threats or release to the environment, and recognized hazardous and environmentally unsound } \\
\text { conditions to their managers. }\end{array}$ \\
\hline A25 & Work management teams complete port-job reviewa, which include reviews of the accuracy and completeness of the AHA. \\
\hline A26 & $\begin{array}{l}\text { Line manngers use feedback from lessons learned, employee concerns, ORPS reports, incidents inventigations and performanoe indicator trenda to: } \\
\text { - Modify training as appropriate } \\
\text { - Revise work indructions and procedures as appropriate } \\
\text { - Engineer new methods of accomplishing work. }\end{array}$ \\
\hline A27 & $\begin{array}{l}\text { Line manegers eatablish methods to obtain employee feedback and addreases employee concerns, providing the opportunity for employees at all levels to } \\
\text { identify ES\&H improvememts or voice ES\&H concerms. }\end{array}$ \\
\hline A28 & Workers conduct themuelves according to the Codes Of Conduct and Marter Safety Rules. \\
\hline
\end{tabular}

